\title{
Radioactive Demonstration of Caustic Recovery from Low-Level Alkaline Nuclear Waste by an Electrochemical Separation Process
}

by

D. T. Hobbs

Westinghouse Savannah River Company

Savannah River Site

Aiken, South Carolina 29808

This paper was prepared in connection with work done under the above contract number with the U.S. Department of Energy. By acceptance of this paper, the publisher and/or recipient acknowledges the U.S. Government's right to retain a nonexclusive, royalty-free license in and to any copyright covering this paper, along with the right to reproduce and to authorize others to reproduce all or part of the copyrighted paper. 


\section{DISCLAIMER}

This report was prepared as an account of work sponsored by an agency of the United States Government. Neither the United States Government nor any agency thereof, nor any of their employees, makes any warranty, express or implied, or assumes any legal liability or responsibility for the accuracy, completeness, or usefulness of any information, apparatus, product, or process disclosed, or represents that its use would not infringe privately owned rights. Reference herein to any specific commercial product, process, or service by trade name, trademark, manufacturer, or otherwise does not necessarily constitute or imply its endorsement, recommendation, or favoring by the United States Government or any agency thereof. The views and opinions of authors expressed herein do not necessarily state or reflect those of the United States Government or any agency thereof.

This report has been reproduced directly from the best available copy.

Available to DOE and DOE contractors from the Office of Scientific and Technical Information, P.O. Box 62, Oak Ridge, TN 37831; prices available from (615) 576-8401.

Available to the public from the National Technical Information Service, U.S. Department of Commerce; 5285 Port Royal Road, Springfield, VA 22161. 


\section{DISCLAIMER}

Portions of this document may be illegible electronic image products. Images are produced from the best available original document. 
WSRC-TR-97-00363

Revision 0

\section{Radioactive Demonstration of Caustic Recovery \\ from Low-Level Alkaline Waste \\ by an Electrochemical Separation Process}

D. T. Hobbs

Publication Date: April 15, 1998

Westinghouse Savannah River Company

Savannah River Technology Center

A iken, SC 29808

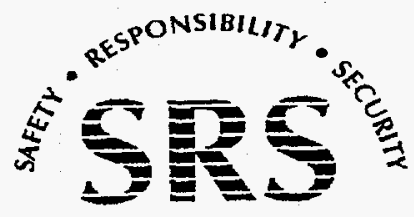

SAVANNAH RIVER SITE 


\section{SUMMARY}

Bench-scale radioactive tests successfully demonstrated an electrochemical process for the recovery of sodium hydroxide (caustic) from Decontaminated Salt Solution produced from the In-Tank Precipitation and Effluent Treatment Processes at the Savannah River Site (SRS). This testing evaluated two membranes: an organic-based membrane, Nafion ${ }^{\circledR}$ Type 350, manufactured by E. I. duPont de Nemours \& Company, Inc. (DuPont) and an inorganic-based membrane, NAS D, being developed by Ceramatec ${ }^{\circledR}$. Both membranes successfully separated caustic from radioactive SRS waste.

Key findings of the testing indicate the following attributes and disadvantages of each membrane. The commercially-available Nafion ${ }^{\circledR}$ membrane proved highly conductive. Thus, the electrochemical cell can operate at high current density minimizing the number of cells at the desired volumetric processing rate. Testing indicated cesium transported across the Nafion ${ }^{\circledR}$ membrane into the caustic product. Therefore, the caustic product will contain low-levels of radioactive cesium due to the presence of ${ }^{134,137} \mathrm{Cs}$ in the waste feed. To meet customer requirements, a post treatment stage may prove necessary to remove radiactive cesium resulting in increased overall process costs and decreased cost savings. In contrast to the Nafion ${ }^{\circledR}$ membrane, the NAS D membrane demonstrated the production of caustic with much lower levels of gamma radioactivity $\left({ }^{137} \mathrm{Cs}\right.$ activity was $\leq 51$ $\mathrm{dpm} / \mathrm{g}$ ). Therefore, the caustic product could possibly release for onsite/offsite use without further treatment. The NAS D membrane remains in the development stage and does not exist as a commercial product. Operating costs and long-term membrane durability remain unknown.

Caustic recovery has been successfully demonstrated in a bench-scale, 2-compartment electrochemical reactor operated for brief periods of time with simulated and radioactive waste solutions and two different types of membranes. The next phase of testing should be directed at (1) demonstrating caustic recovery in pilot-scale equipment and (2) determining membrane and other cell component performance over an extended period of time (minimum of 1000 hours). This information is necessary to verify key criteria which will be used to perform facility design and cost evaluations.

\section{INTRODUCTION}

High-level waste (HLW) stored at the Hanford and Savannah River sites contain large amounts of sodium salts that can, in principle, be recovered as sodium hydroxide for recycling. For example, the sodium ions can be separated from the other components in the HLW by electrochemical salt splitting. In the electrochemical salt splitting process, sodium ions migrate across a cation-selective membrane under the influence of an applied electrical potential. In a two compartment cell in which the membrane separates the two electrodes, the HLW waste stream enters into the anolyte compartment (see Figure 1). Sodium ions migrate across the membrane into the catholyte. Hydroxide forms at the cathode by the reduction of water. The catholyte product is thus a sodium hydroxide solution. Anionic species such as nitrate, aluminate, and sulfate do not pass through the membrane, and therefore, are retained in the feed stream compartment of the electrochemical cell. 
A number of ion-selective membranes have been developed for industrial electrochemical processes the manufacture of inorganic and organic chemicals, the recovery of metals, water purification and effluent treatment [1]. Organic-based membranes, such as the commercially-available perfluorinated membranes, have been used extensively in the chlor-alkali industry and increasingly in salt splitting applications such as the production of sodium hydroxide and sulfuric acid from sodium sulfate solutions [2]. These membranes exhibit excellent chemical stability over a wide range of $\mathrm{pH}$ values. Ion-selective inorganic-based membranes have not been deveoped as extensively as organic-based membranes. Recently, a new inorganic membrane based on the family of sodium ion conductors, referred to as $\mathrm{NaSICON}^{\circledR}$ materials [3], has exhibited excellent selectivity for recovering sodium highly alkaline salt solutions [4]. Inorganic membranes are attractive candidates in this application due to their inherently higher radiation stability compared to organic materials.

Previously, a statistically designed set of tests determined the effects of key operating parameters and variations in the waste composition for the recovery of caustic from simulated SRS waste [5]. Caustic was recovered from the simulated Decontaminated Salt Solutin at high electrical efficiency using an organic-based membrane. Testing at the Pacific Northwest National Laboratory (PNNL) demonstrated caustic recovery from simulated Hanford waste streams with a ceramic membrane [6]. At the request of Tanks Focus Area Program, Savannah River Technology Center (SRTC) conducted a demonstration of caustic recovery using radioactive SRS waste at the bench-scale during FY97 [7]. This report details the results of the radioactive demonstration testing. 
Figure 1. Diagram of Electrochemical Salt Splitting Process for the Recovery of Sodium Hydroxide from Alkaline Salt Solutions

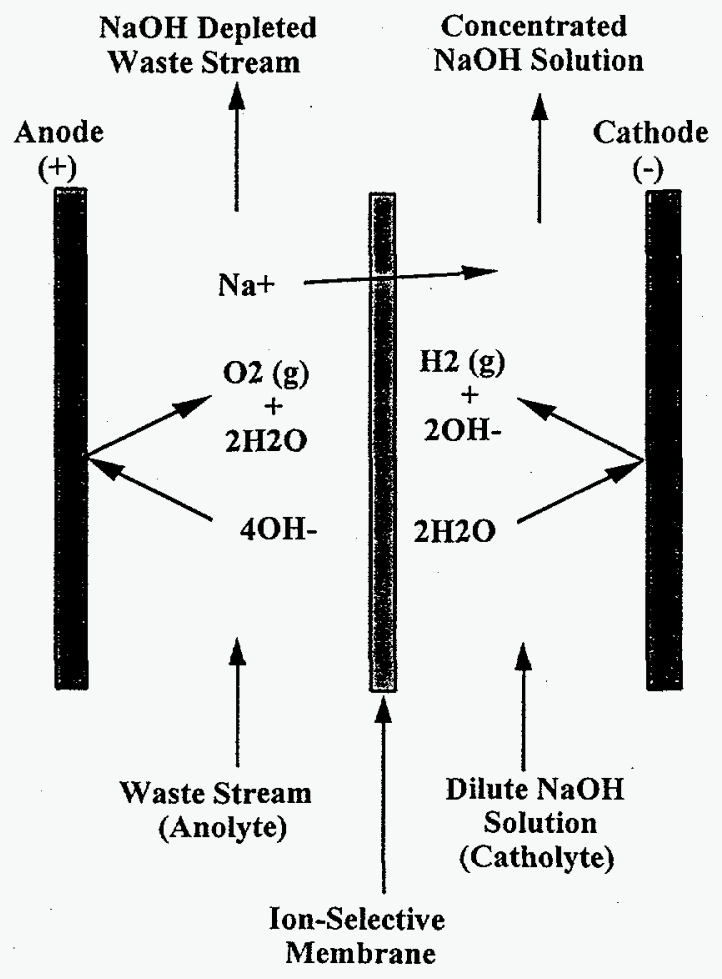

\section{EXPERIMENTAL}

Figure 2 provides a schematic diagram of the experimental equipment used in the demonstration tests. The system consisted a MP electrolyzer manufactured by ElectroCell AB (Sweden) equipped with either a nickel or platinized titanium cathode and a platinized titanium anode, two rotameters (PVDF shell with EPPM sealing O-rings), two March model \#AC-3C-MD centrifugal pumps (PVD-lined) and two 2.0 liter glass reservoirs equipped with glass condensers. Electrical power to the cell was provided by a Hewlett Packard \# 6011-A DC power supply. The electrochemical cell was divided into two compartments by the insertion of a membrane. Membranes tested included Nafion ${ }^{\circledR}$ Type 350 membrane manufactured by DuPont and the NAS D ceramic membrane manufactured by the Ceramatec ${ }^{\circledR}$ Corporation (Salt Lake City, UT). The ceramic membrane assembly consisted of 8 circular membrane disks $(2.5 \mathrm{~cm}$ in diameter and 0.14 $\mathrm{cm}$ in thickness) secured in a polyethylene scaffold with PVDF O-rings. The total available membrane area in the scaffold assembly is $22 \mathrm{~cm}^{2}$. A photograph of the membrane assembly is provided in Figure 3.

Tests used radioactive waste obtained from the Salt Solution Hold Tank at the SRS Saltstone Production Facility (sample received at SRTC on November 20, 1996). The liquid phase composition of the slurry is shown in Table I. Major components included 
nitrate, hydroxide and sodium. The sample contained a small amount of undissolved solids. The solids were not characterized.

\section{Table I. Composition and Properties of the Effluent Treatment Facility Concentrate}

\begin{tabular}{ll} 
Species & Concentration \\
\cline { 2 - 2 } Sodium & $5.1 \mathrm{E}+00 \mathrm{M}$ \\
Nitrate & $2.23 \mathrm{E}+00 \mathrm{M}$ \\
Hydroxide & $1.57 \mathrm{E}+00 \mathrm{M}$ \\
Nitrite & $2.68 \mathrm{E}-01 \mathrm{M}$ \\
Sulfate & $1.5 \mathrm{E}-01 \mathrm{M}$ \\
Aluminum & $1.1 \mathrm{E}-01 \mathrm{M}$ \\
Oxalate & $8.6 \mathrm{E}-03 \mathrm{M}$ \\
Fluoride & $6.2 \mathrm{E}-03 \mathrm{M}$ \\
Chloride & $1.4 \mathrm{E}-02 \mathrm{M}$ \\
Phosphate & $<1.0 \mathrm{E}-03 \mathrm{M}$ \\
${ }^{137} \mathrm{Cs}$ & $2.8 \mathrm{E}+03 \mathrm{dpm} / \mathrm{mL}$ \\
${ }^{106} \mathrm{Ru}$ & $1.1 \mathrm{E}+03 \mathrm{dpm} / \mathrm{mL}$ \\
${ }^{125} \mathrm{Sb}$ & $4.7 \mathrm{E}+03 \mathrm{dpm} / \mathrm{mL}$ \\
${ }^{126} \mathrm{Sb}$ & $8.4 \mathrm{E}+02 \mathrm{dpm} / \mathrm{mL}$ \\
${ }^{126} \mathrm{Sn}$ & $2.5 \mathrm{E}+02 \mathrm{dpm} / \mathrm{mL}$ \\
${ }^{90} \mathrm{Sr}$ & $1.6 \mathrm{E}+03 \mathrm{dpm} / \mathrm{mL}$ \\
${ }^{99} \mathrm{Tc}$ & $2.67 \mathrm{E}+04 \mathrm{dpm} / \mathrm{mL}$ \\
${ }^{D e n s i t y ~}$ & $1.238 \mathrm{~g} / \mathrm{mL}$
\end{tabular}

To initiate a test, the radioactive waste was placed in the anolyte reservoir and a 1.0 molar solution of sodium hydroxide placed in the catholyte reservoir. Each pump was activated, flowrates for each solution adjusted to the same value and the system checked for liquid leaks. The DC power supply was then turned on and the current slowly increased to the desired current density. Temperatures of the anolyte and catholyte solutions were measured in each reservoir with glass thermometers. Current and voltage were recorded from the DC power supply display. Current was confirmed by measuring the voltage across a shunt using a Fluke model 25 multimeter.

Catholyte and anolyte samples were taken periodically during each test. Sodium concentrations were determined by inductively coupled plasma esmission spectroscopy (ICP-ES) or atomic absorption spectroscopy (AAS). Nitrate, nitrite, sulfate, oxalate, phosphate, fluoride and chloride concentrations were determined by ion chromatography. Hydroxide concentration were determined by a titrimetric method. Gamma activities were determined by gamma spectroscopy. 
Figure 2. Schematic Diagram of the Radioactive Bench-Scale Test Equipment

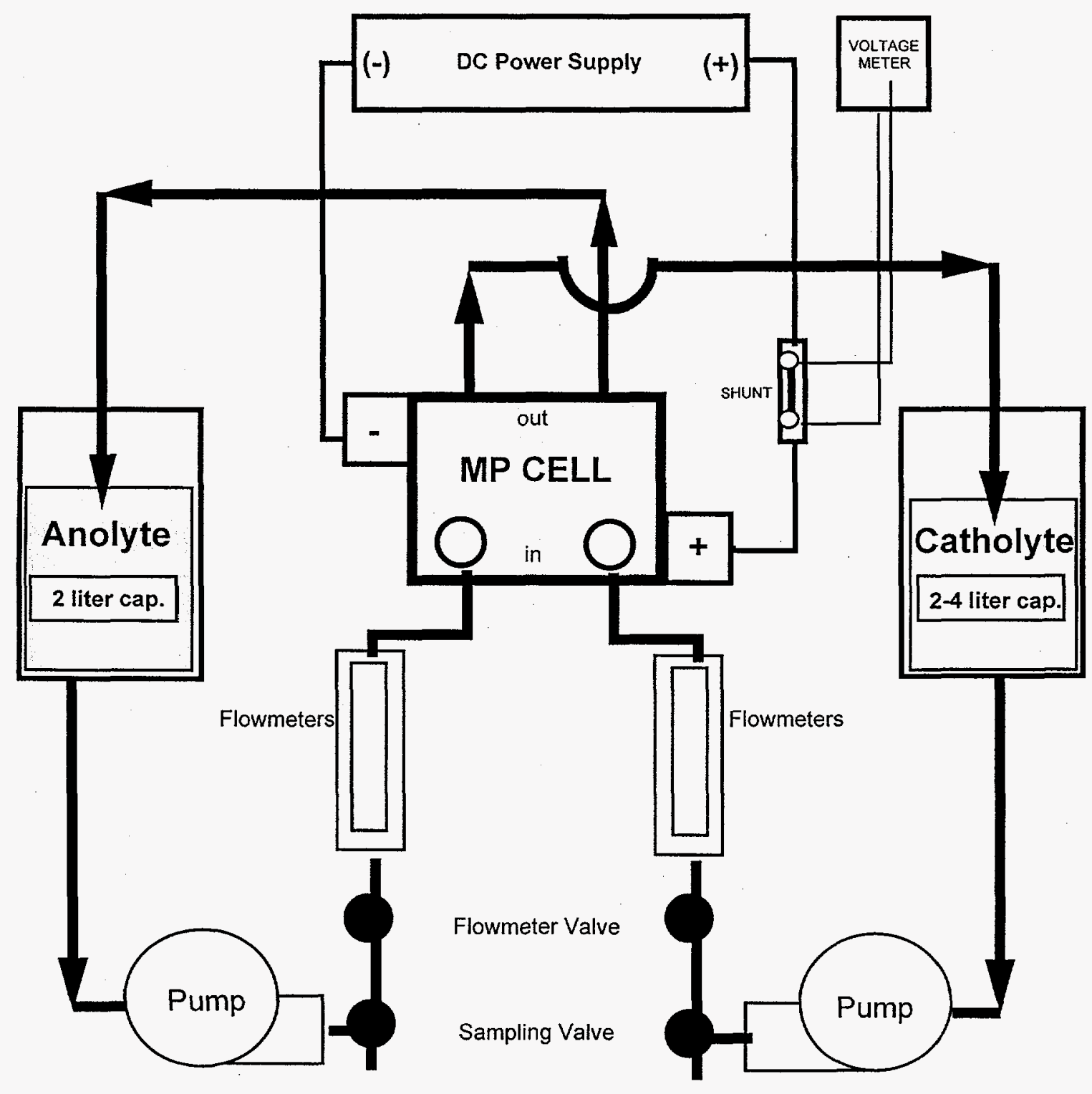


Figure 3. Photograph of the Ceramic Membrane Scaffold Assembly (view of scaffold and membrane disks after Test CR19)

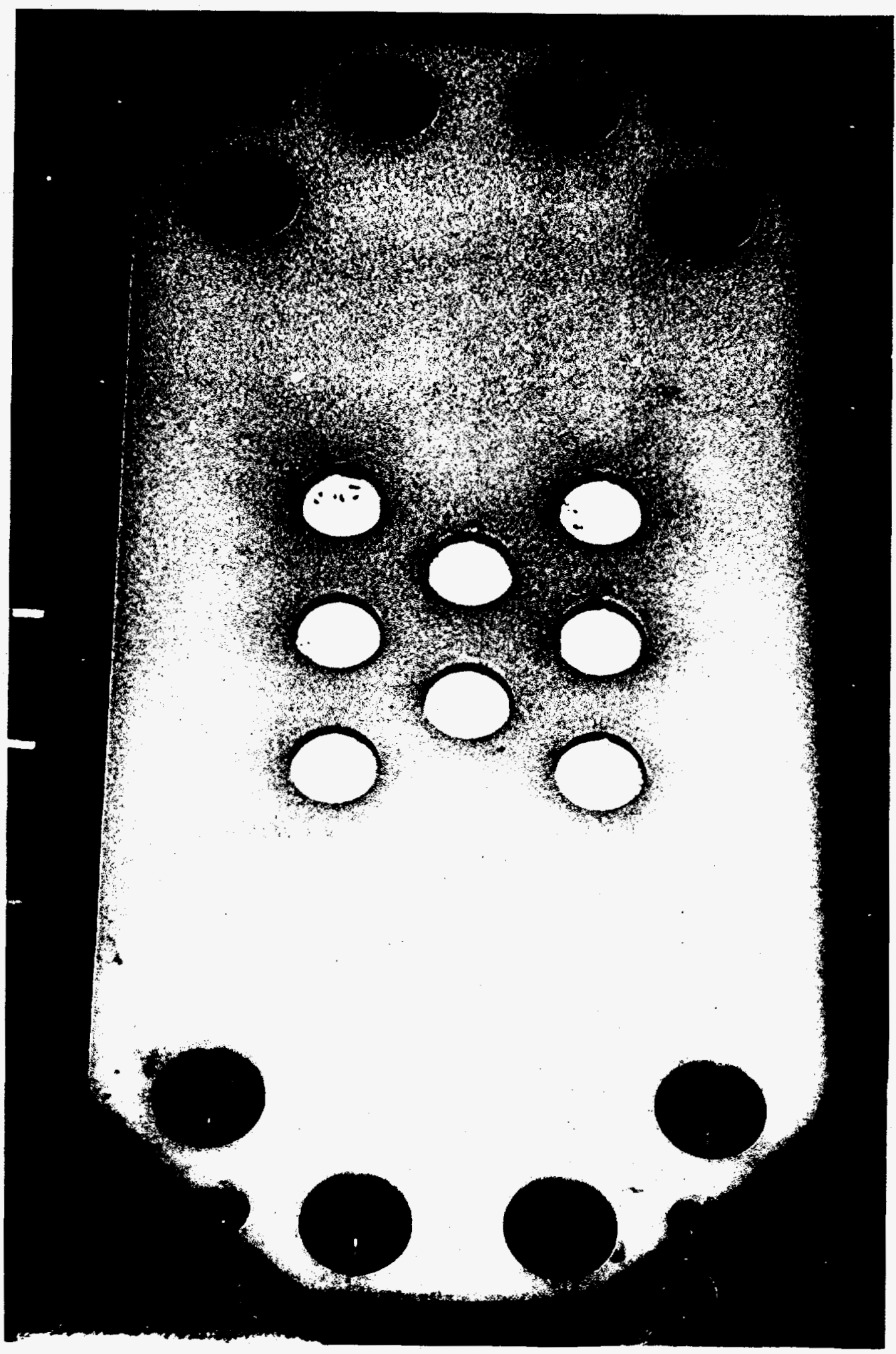




\section{RESULTS AND DISCUSSION}

A total of five radioactive tests were conducted to demonstrate the feasibility of caustic recovery from SRS Decontaminated Salt Solution. The tests used radioative waste with and without electrolytic treatment to convert nitrate/nitrite to hydroxide, two different anode materials (nickel and platinized/titanium) and two different membranes, Nafion ${ }^{\circledR}$ Type 350 and Ceramatec ${ }^{\circledR}$ Type NAS D. Four of the tests used a polarized electrochemical cell. A fifth test was conducted with the as-received waste and $\mathrm{Nafion}^{\circledR}$ membrane without the cell polarized to determine the rate of transport of radiochemical species across the membrane in the absence of an applied electrical field. A summary of the test conditions is provided in Table II.

\section{Table II. Radioactive Test Conditions}

\begin{tabular}{|c|c|c|c|c|c|}
\hline Condition & CR15 & CR16 & CR17 & CR18 & CR19 \\
\hline Cathode & $\mathrm{Ni}$ & $\mathrm{Ni}$ & $\mathrm{Ni}$ & $\mathrm{Ni}$ & $\mathrm{Ni}$ \\
\hline Anode & $\mathrm{Pt} / \mathrm{Ti}$ & $\mathrm{Pt} / \mathrm{Ti}$ & $\mathrm{Ni}$ & $\mathrm{Ni}$ & $\mathrm{Pt} / \mathrm{Ti}$ \\
\hline Waste Type ${ }^{a}$ & DSS & DSS & ET-DSS & DSS & ET-DSS \\
\hline Membrane $^{\mathrm{b}}$ & Nafion ${ }^{\infty}$ & Nafion $^{\otimes}$ & Nafion $^{\circledast}$ & NAS D & NAS D \\
\hline Current Density $\left(\mathrm{amp} / \mathrm{m}^{2}\right)$ & 2500 & 0 & 3500 & 300 & 300 \\
\hline Voltage (V) & 6.7 & 0 & 6.2 & 5.0 & 5.6 \\
\hline Anolyte Temp. $\left({ }^{\circ} \mathrm{C}\right)$ & $40 \pm 2$ & $28 \pm 1$ & $42 \pm 4$ & $26 \pm 2$ & $28 \pm 2$ \\
\hline Catholyte Temp. $\left({ }^{\circ} \mathrm{C}\right)$ & $36 \pm 1$ & $28 \pm 1$ & $41 \pm 2$ & $28 \pm 2$ & $30 \pm 1$ \\
\hline Run Time (h) & 3.5 & 4.0 & 5.3 & 104 & 70 \\
\hline Total Charge (C) & $3.15 \mathrm{E}+05$ & 0 & $6.72 \mathrm{E}+05$ & $2.08 \mathrm{E}+05$ & $2.03 E+05$ \\
\hline Initial Anolyte Vol. (L) & 1.5 & 1.50 & 1.50 & 1.50 & 0.98 \\
\hline Final Anolyte Vol. (L) & 1.27 & 1.45 & 1.08 & 1.30 & 0.91 \\
\hline Inital Catholyte Vol. (L) & 4.00 & 4.00 & 1.50 & 1.50 & 1.50 \\
\hline Final Catholyte Vol. (L) & 4.20 & 4.00 & 1.85 & 1.20 & 1.40 \\
\hline
\end{tabular}

After Test CR16, the test equipment was modified to operate with a smaller catholyte volume $(1.5 \mathrm{~L}$ versus $4.0 \mathrm{~L})$. The smaller volume allows more sensitive detection of trace impurities entering the catholyte from the anolyte. In Test CR16 (absence of applied electric field), there was negligible volume change in the anolyte and catholyte. The change in the anolyte volume 
for Test CR16 is attributed solely to the aliquot volume of samples taken during the test. In the tests with the Nafion ${ }^{\circledR}$ membrane, the volume of the anolyte decreased and the volume of the catholyte increased due to transport of water across the membrane. Water transport across the Nafion ${ }^{\otimes}$ membrane is well documented [8]. In contrast to the tests with the Nafion ${ }^{\circledR}$ membrane, the volume of the anolyte and catholyte both decreased during the tests with the ceramic membrane. Sodium transport across the ceramic membrane does not involve water [3] and, therefore, the volumes would be expected to remain the same. The losses are attributed to the aliquots taken for analysis, leaks and residual solution remaining in lines.

Nickel and platinized titanium (Pt/Ti) anodes were used with each membrane type. Higher cell voltages were observed with a $\mathrm{Pt} / \mathrm{Ti}$ anode than with a nickel anode. Although there were some differences in current density and solution composition among the four tests, the major contributor to the higher cell voltage is attributed to the higher anode potential for Pt/Ti reported previously in the electrolytic destruction of nitrate and nitrite [9-11].

There was evidence of attack of the nickel anode at the higher current density $\left(3500 \mathrm{amp} / \mathrm{m}^{2}\right.$ in Test CR17 versus $2500 \mathrm{amp} / \mathrm{m}^{2}$ in Test CR15). After disassembling the cell upon completion of Test CR17, a small quantity of light green granular solids identified as nickel hydroxide, $\left.\left[\mathrm{Ni}(\mathrm{OH})_{2}\right)\right]$, was found in the anolyte side of the cell. No solids were observed in Test CR15 or either of the tests with the inorganic membrane.

\section{Results with Nafion $^{\circledR}$ Type 350 Membrane}

Figure 4 shows the change in moles of sodium and hydroxide in the catholyte and anolyte as a function of charge passed for Test CR15. Over the test period, the change in moles in each compartment was observed to be linear with the charge passed indicating that the rate of transport is current limited. Using the slope of the fitted lines, the current efficiency determined as $92 \%$ for transport of sodium into the catholyte and $93 \%$ for transport of sodium out of the anolyte. The high current efficiency $(>90 \%)$ for sodium transport agrees well with that previously measured with simulated salt solutions [5]. 
Figure 4. Moles of Sodium and Hydroxide versus Charge Passed (Test CR15)

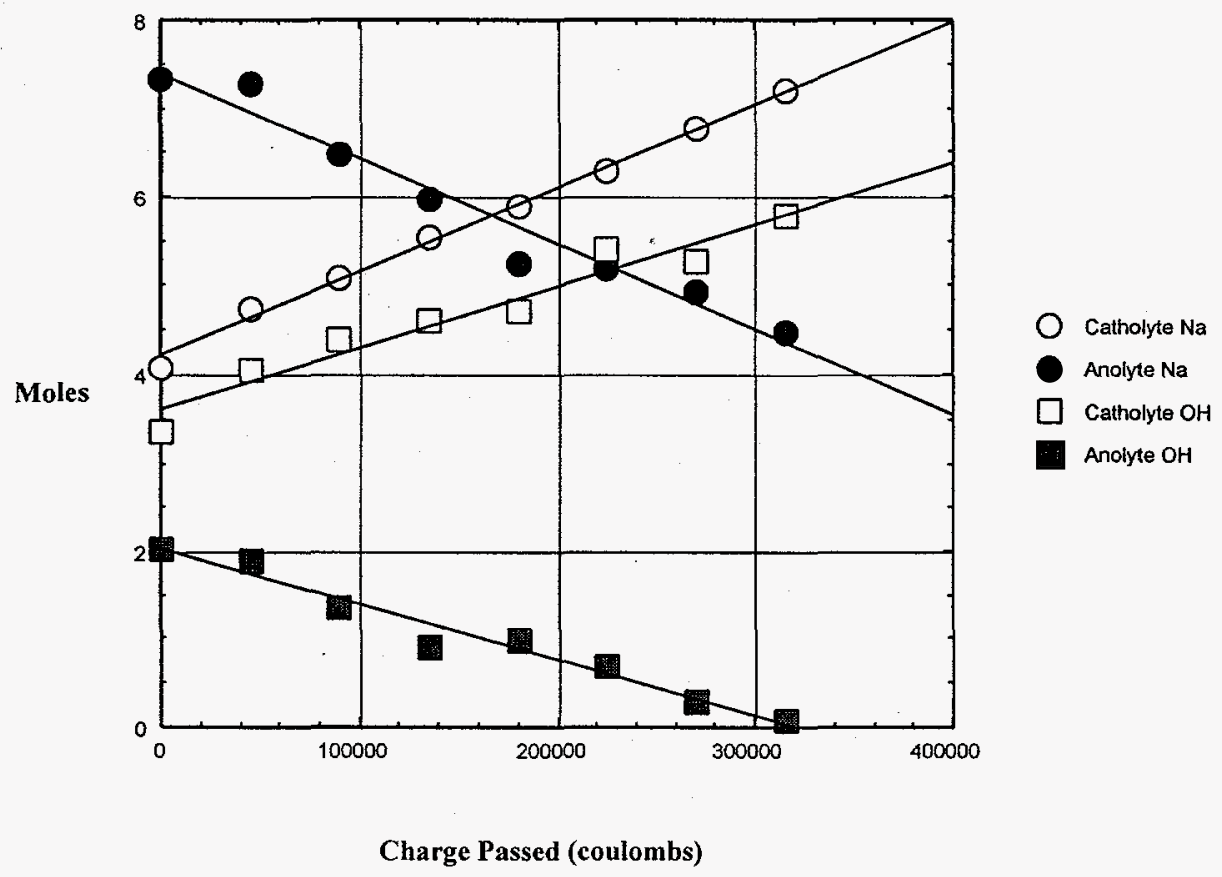

Absent other reactions or errors, the efficiency for hydroxide formation or depletion should equal that for transport of sodium. However, the efficiency of hydroxide formation and depletion was well below that determined for sodium in both the catholyte and anolyte (see Table III). The lower efficiency in the anolyte compared to the catholyte is attributed to a portion of the current involved in the oxidation of nitrite to nitrate instead of hydroxide oxidation. The overall lower hydroxide formation is attributed to analytical biases in the determination of hydroxide and sodium. Also, since air is not excluded from contacting the alkaline solutions, some of the hydroxide could have been converted to carbonate by reaction with atmospheric carbon dioxide.

Table III. Electrical Efficiencies for Transport of Sodium and Depletion and Formation of Hydroxide in Radioactive Tests

Electrical Efficiency (\%)

\begin{tabular}{rccccc} 
& \multicolumn{2}{c}{ Catholyte } & \multicolumn{2}{c}{ Anolyte } \\
Test ID & Sodium & Hydroxide & & Sodium & Hydroxide \\
CR15 & 92 & 67 & & 93 & 61 \\
CR17 & 69 & 64 & 67 & 49 \\
CR18 & 84 & 48 & 160 & 110 \\
CR19 & 99 & 75 & 110 & 110
\end{tabular}


Prior to Test CR17, the waste was treated to electrochemically convert the nitrate and nitrite to hydroxide. Figure 5 provides a plot of the change in moles of sodium and hydroxide in the anolyte and catholyte solutions as a function of charge passed. The current efficiencies for sodium transport showed good agreement: $69 \%$ for the catholyte and $67 \%$ for the anolyte. The current efficiencies in this test were lower than in Test CR15. The steady-state catholyte and anolyte temperatures in Test CR17 were $2-5^{\circ} \mathrm{C}$ higher than in Test CR15. Although the current density in CR17 was higher $\left(3500 \mathrm{amps} / \mathrm{m}^{2}\right)$ than in CR15 $\left(2500 \mathrm{~A} / \mathrm{m}^{2}\right)$, the cell voltage was lower (6.2 V versus 6.7 V). The anolyte in Test CR17 had a lower initial salt concentration (e.g., initial anolyte $\left[\mathrm{Na}^{+}\right]$was $4.9 \mathrm{M}$ in Test $\mathrm{CR} 15$ and $3.7 \mathrm{M}$ in Test CR17). The lower current efficiency in Test CR17 is attributed to the higher current density resulting in energy losses due to ohmic heating.

The hydroxide concentration decreased in the anolyte and increased in the catholyte. The efficiency for hydroxide formation in the catholyte agreed well with that for sodium transport (69\% versus $64 \%$ ). Agreement was not as good for the anolyte (67\% versus $49 \%$ ). However, both are in better agreement than that found in Test CR15 (see Table III). The better agreement is consistent with less current involved in nitrite oxidation in CR17 since the initial nitrite concentration in CR17 $(0.025 \mathrm{M})$ is a factor of 10 lower than in CR15 $(0.27 \mathrm{M})$. 
Figure 5. Moles of Sodium and Hydroxide versus Charge Passed (Test CR17)

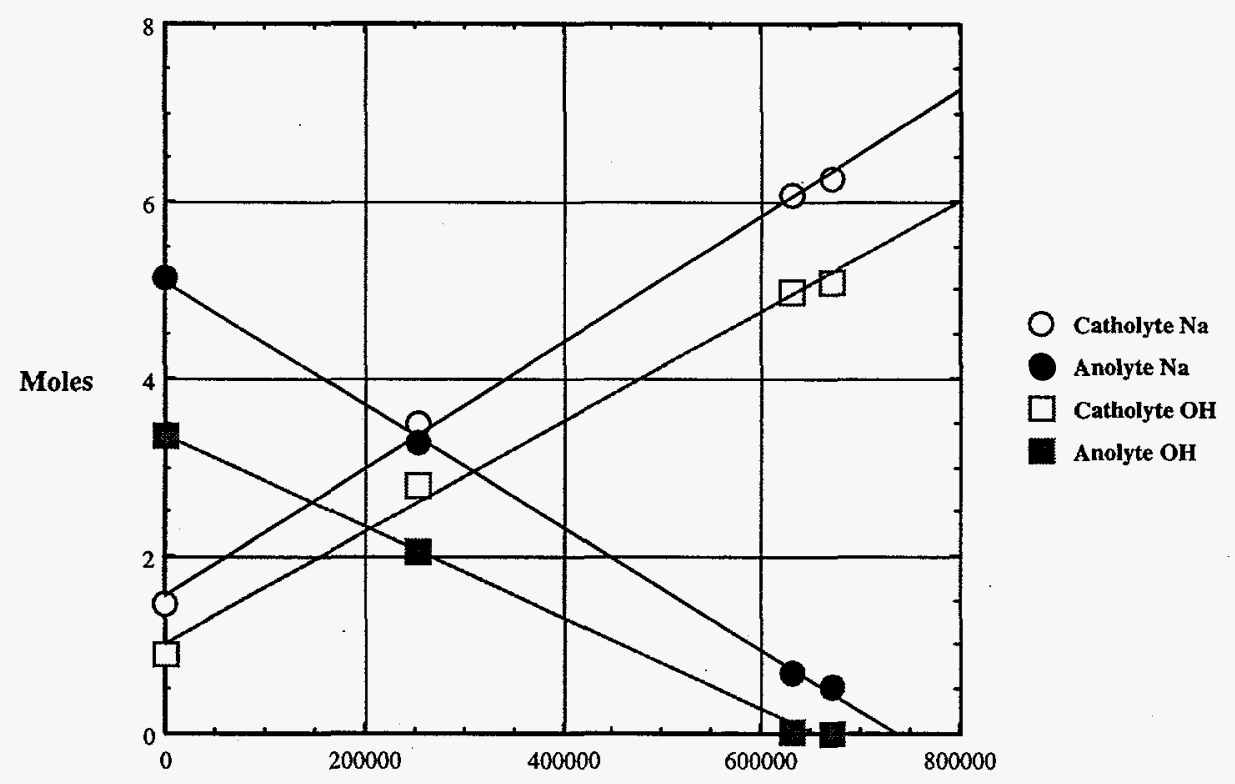

Charge Passed (coulombs)

Test CR16 was identical to CR15 with the exception that the cell was not polarized. The objective of the test was to determine if the ${ }^{137} \mathrm{Cs}$ observed in the catholyte product was due to electrically driven transport or due to diffusion and leaks. Table IV provides the results. A much lower concentration of ${ }^{137} \mathrm{Cs}$ was observed in the catholyte without polarization. Based on the quantity of ${ }^{137} \mathrm{Cs}$ found in the catholyte of Test CR16, cesium transport due to diffusion and leaks accounts for less than $5 \%$ of the cesium found in the catholyte under polarized conditions.

Cesium ion has a higher ionic mobility and smaller hydrated radius than sodium ion [12] as well as a higher selectivity for the Nafion ${ }^{\oplus}$ membrane [8]. Relative migration ratios for cesium and sodium in these tests confirmed the expected trend. After normalizing the measured fluxes of cesium and sodium to initial anolyte concentrations in Tests CR15 and CR17, the ratio of cesium to sodium migration is greater than 1.0 indicating a preference for cesium migration compared to sodium. The overall higher quantity of sodium migrated compared to cesium is due to the high sodium concentration (ca. 3-5M) compared to cesium (ca. 1E-07M).

No other gamma-emitting radionuclides were detected in the catholyte samples. Isotopes of ruthenium, technetium, tin and antimony which were detected in the feed solution are present as anionic or neutral oxy complexes and, therefore, would not likely transport across the membrane under the influence of an applied electrical field. ${ }^{90}$ Strontium, a $\beta$-emitter, may transport if present. The final catholyte samples were not analyzed for ${ }^{90}$ Strontium. However, ICP-ES analysis of the final catholyte samples did not indicate the transport of any strontium into the 
catholyte. Based on the detection limit for strontium and the quantity of catholyte, the transport of strontium is determined at $\leq 1 \mathrm{E}-11 \mathrm{~mole} /$ coulomb.

Table IV. ${ }^{137}$ Cesium Mass Balance

\begin{tabular}{|c|c|c|c|c|c|}
\hline \multicolumn{6}{|c|}{$\mu \mathrm{Ci}$ of ${ }^{137} \mathrm{Cs}$} \\
\hline \multirow[b]{2}{*}{ Test ID } & \multicolumn{2}{|c|}{ Anolyte } & \multicolumn{2}{|c|}{ Catholyte } & \multirow[b]{2}{*}{$\%$ Recovered } \\
\hline & Initial & Final & Initial & Final & \\
\hline CR15 & 1.78 & 0.577 & bdl & 1.26 & 103 \\
\hline CR16 & 1.82 & 1.71 & bdl & 0.16 & 103 \\
\hline CR17 & 1.12 & $\leq 0.148$ & bdl & 1.44 & 129 \\
\hline CR18 & 1.77 & 1.56 & $\leq 0.00976$ & $\leq 0.018$ & 89.3 \\
\hline CR19 & 0.962 & 0.904 & $\leq 0.0240$ & $\leq 0.036$ & 97.7 \\
\hline
\end{tabular}

Sodium was the only element detected by ICP-ES analysis to increase in the catholyte and decrease in the anolyte during Test CR15 (see Appendix 2A). In addition to sodium, aluminum and possibly calcium increased in the catholyte and decreased in the anolyte in Test CR17 (see Appendix 2B). Essentially all of the aluminum was removed from anolyte as a result of the depletion of free hydroxide in the anolyte (see Figure 4). Visual inspection revealed the formation of a white solid $\left(\mathrm{Al}(\mathrm{OH})_{3}\right)$ during the latter stage of Test CR17. From the ICP-ES data, aluminum transported at a rate of $2.4 \mathrm{E}-09$ mole/coulomb and calcium transported at 1.2E-11 mole/coulomb. These rates are 3-5 orders of magnitude lower than that measured for sodium.

\section{Results with Ceramatec ${ }^{\circledR}$ NAS D Membrane}

Tests CR18 and CR19 were similar to Tests CR15 and CR17, respectively, except the inorganic NAS D membrane supplied by the Ceramatec ${ }^{\circledR}$ Company (see Table II) was used in place of the Nafion $^{\infty}$ membrane. For both tests, recovery of sodium hydroxide from the radioactive waste was demonstrated as evidenced by the sodium hyroxide concentrations decreasing in the anolyte and increasing in the catholyte (see Figures 6 and 7).

The current density in the tests with the NAS D membrane was selected based on the manufacturer's recommendation and ranged from a factor of 8 to 12 lower than that with the Nafion ${ }^{\otimes}$ membrane. Consequently, the tests were conducted for a longer time period (see Table II) to pass a comparable quantity of charge. The voltage ranged from 1.2 to $1.7 \mathrm{~V}$ lower with the ceramic membrane than those with the Nafion ${ }^{\circledR}$ membrane. 
(CR19). Mass balance for sodium hydroxide was poor in Test CR18. The change in moles of hydroxide in the catholyte was a factor 2.4 times lower than sodium. The quantity of sodium transported out of the anolyte was a factor of 1.7 times greater than that found transported into the catholyte. The cause of the poor mass balance is not known, but is believed due to analytical errors. Final catholyte and anolyte volumes are below that expected based on losses due to sample aliquots and evaporation. However, the lower solution volumes cannot explain the observed behavior since changes in the moles of sodium and hydroxide were not consistently lower, but were both higher and lower.

Good agreement in the mass balance of sodium hydroxide was found in Test CR19. As in the tests with the Nafion ${ }^{\otimes}$ membrane, there appeared to be slightly more sodium hydroxide lost from the anolyte than appeared in the catholyte and slightly lower levels of hydroxide than sodium.

The inorganic membrane exhibited higher selectivity for sodium versus cesium than the organic membrane. No ${ }^{137} \mathrm{Cs}$ or other gamma-emitting radionuclide was detected in any of the final catholyte samples (see Table III). The NAS D membrane reportedly only transports sodium ions due to the lattice structure [5]. The crystal radius of cesium is approximately $50 \%$ higher than that of sodium and, therefore, cesium is not transported.

Sodium was the only element detected by ICP-ES analysis to increase in the catholyte and decrease in the anolyte during Test CR18 (see Appendix 2C). In addition to sodium, calcium increased in the catholyte and decreased in the anolyte in Test CR19 (see Appendix 2D). From the ICP-ES data, calcium transported at $2.5 \mathrm{E}-11$ mole/coulomb. This rate is five orders of magnitude lower than that measured for sodium. The calcium transport rates for the two different membranes are very similar. Since the mode of ionic transport is significantly different in the two membranes, the measured transport of calcium is probably not statistically significant. Leakage across both membrane types (including seals) appeared small since aluminum, which is present at much higher concentrations (i.e., approximately $3000 \mathrm{mg} / \mathrm{L}$ ) in the initial anolytes, was found in the final catholyte in only one test (CR17). 
Figure 6. Moles of Sodium and Hydroxide versus Charge Passed (Test CR18)

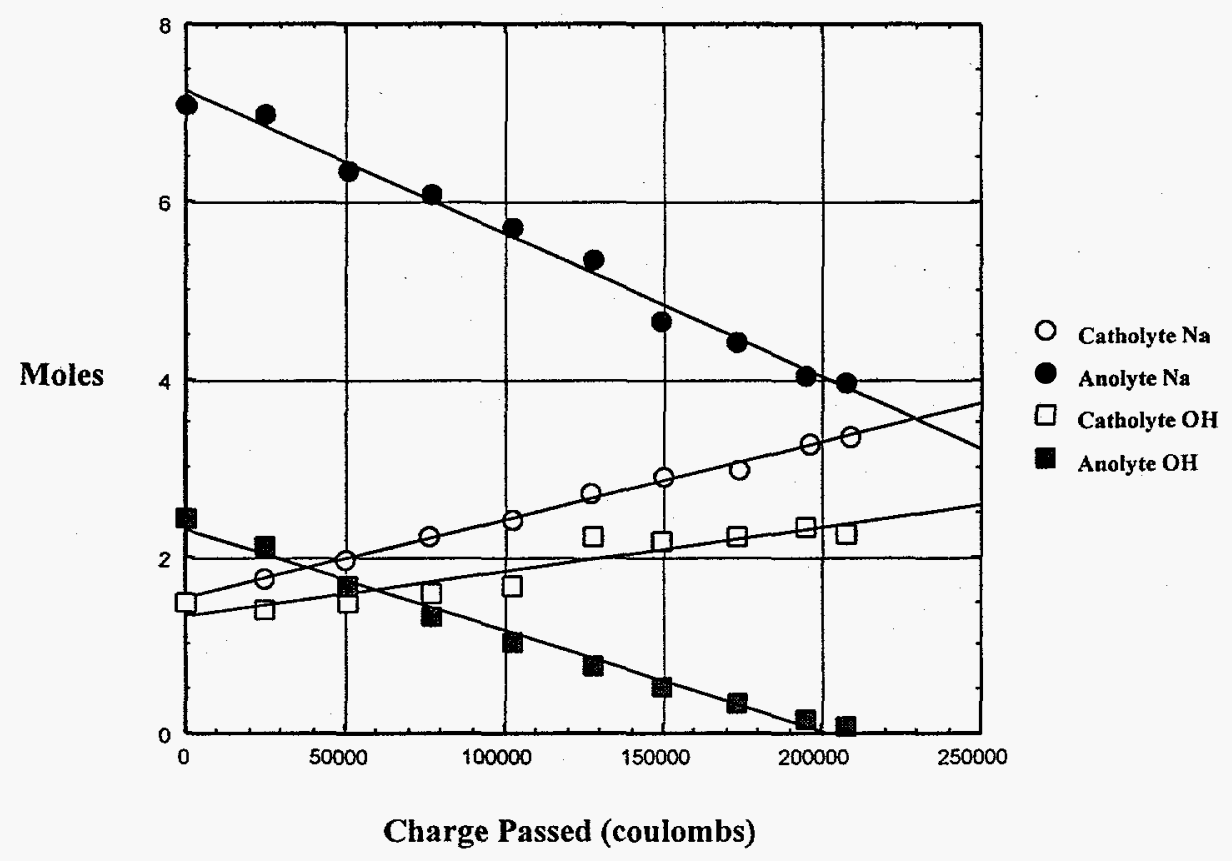

Figure 7. Moles of Sodium and Hydroxide versus Charge Passed (Test CR19)

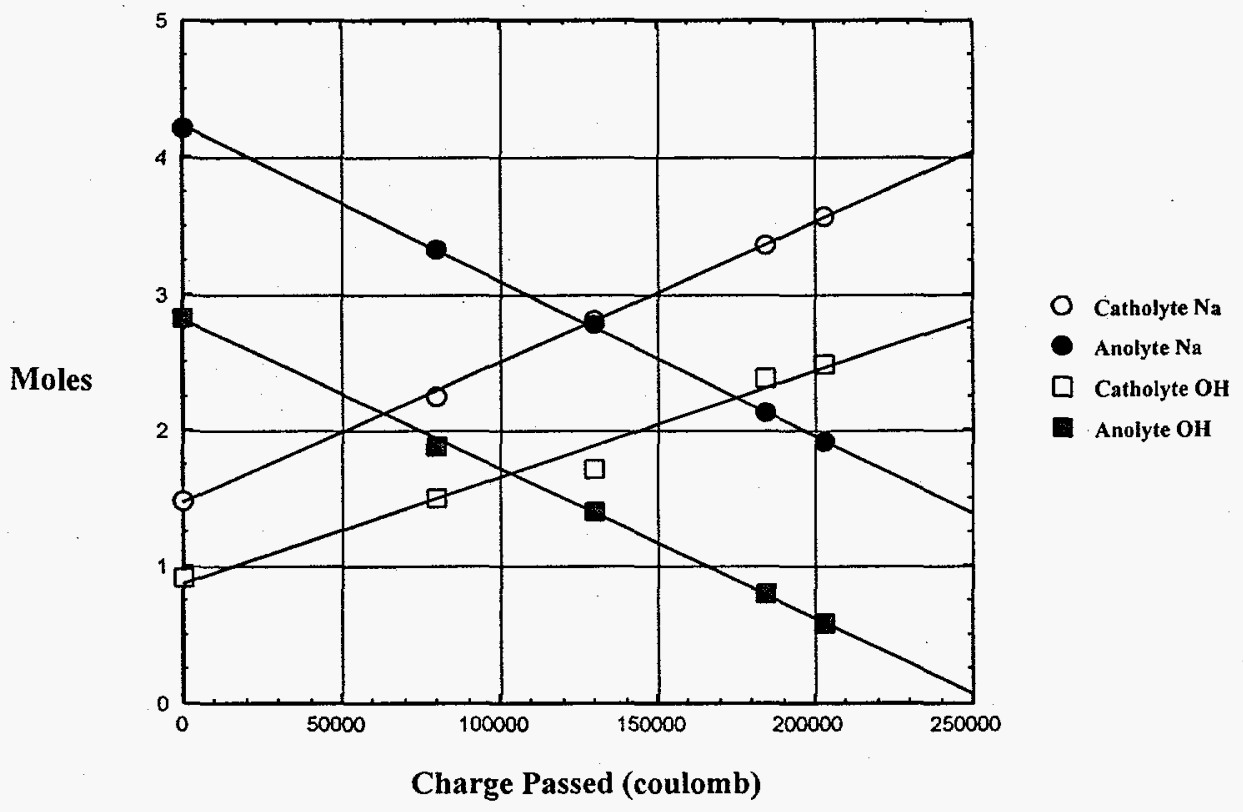




\section{CONCLUSIONS AND RECOMMENDATIONS}

Bench-scale radioactive tests successfully demonstrated an electrochemical process for the recovery of sodium hydroxide (caustic) from Decontaminated Salt Solution produced from the In-Tank Precipitation and Effluent Treatment Processes at the Savannah River Site. Caustic recovery was successful with both types of membranes evaluated, Nafion ${ }^{\otimes}$ Type 350 and Ceramatec $^{\circledR}$ NAS D.

Key test findings indicate the following attributes and disadvantages of each membrane. The commercially-available Nafion ${ }^{\otimes}$ membrane proved highly conductive. Thus, the electrochemical cell can operate at high current density minimizing the number of cells at the desired volumetric processing rate. Testing indicated cesium transported across the Nafion ${ }^{\boxplus}$ membrane into the caustic product. Therefore, the caustic product will contain low-levels of radioactive cesium due to the presence of ${ }^{134,137} \mathrm{Cs}$ in the waste feed. To meet customer requirements, a post treatment stage may prove necessary to remove radiactive cesium resulting in increased overall process costs and decreased cost savings. In contrast to the Nafion ${ }^{\otimes}$ membrane, the NAS D membrane demonstrated the production of caustic from radioactive wastes with much lower levels of gamma radioactivity (i.e., ${ }^{137} \mathrm{Cs}$ activity $\leq 51 \mathrm{dpm} / \mathrm{g}$ ). Therefore, the caustic product could possibly release for offsite use without further treatment. The NAS D membrane remains at the development stage and does not exist as a commercial product. Operating costs and long-term membrane durability remain unknown.

Caustic recovery has been successfully demonstrated in a bench-scale, 2-compartment electrochemical reactor operated for brief periods of time with simulated and radioactive waste solutions and two different types of membranes. The next phase of testing should be directed at (1) demonstrating caustic recovery in pilot-scale equipment and (2) determining membrane and other cell component performance over an extended period of time (minimum of 1000 hours). This information is necessary to verify key criteria which will be used to perform facility design and cost evaluations.

\section{ACKNOWLEDGEMENTS}

The author wishes to acknowledge the contributions of Lin Thacker and Mona Blume in the fabrication and operation of the testing equipment. The work benefitted from technical discussions with Dean Kurath (PNNL), David Genders (Electrosynthesis Company, Inc.), Davor Sutija (Ceramatec ${ }^{\oplus}$ ) and Thom Landro (Ceramatec ${ }^{\circledR}$ ). This work was funded by the Office of Science and Tehnology, Office of Environmental Management through the Tank Focus Area Program, D. W. Geiser, Headquarters Focus Area Team Lead; C. P. McGinnis, Pretreatment Technical Integration Manager; and T. S. Gutman, Technical Program Officer. 


\section{REFERENCES}

1. T. A. Davis, J. D. Genders and D. Pletcher, A First Course in Ion Permeable Membranes, Alresford Press, Ltd., Alresford, England, 1997.

2. M. Paleologou, A. Thibault, P-Y. Wong, R. Thompson and R. M. Berry, Separation and Purification Technology, 11 (1997), 159.

3. D. Sutija, S. Balagopal, T. Landro and J. Gordon, The Electrochemical Society Interface, 5(4) 26-30, 1996.

4. D. E. Kurath, K. P. Brooks, G. W. Hollenberg, D. P. Sutija, T. Landro and S. Balagopal, Separation and Purification Technology, 11 (1997), 185.

5. D. T. Hobbs, "Electrochemical Recovery of Sodium Hydroxide from Alkaline Salt Solutions (U)," WSRC-TR-96-0317, October, 1996.

6. D. E. Kurath, K. P. Brooks, G. W. Hollenberg, S. Balagopal, T. Landro and D. P. Sutija, "Caustic Recycle from Nonradioactive Tank Waste Simulants Using a Ceramic Membrane Salt Splitting Process: FY1997 Experimental Results," Pacific Northwest National Laboratory, January, 1997.

7. D. T. Hobbs, Technical Task Plan SR1-6-WT-41, Subtask 2 - "Caustic Recovery and Recycle," revision 3, April 8, 1996.

8. A. Eisenberg and H. L. Yeager, editors, Perfluorinated Ionomer Membranes, ACS Symposium Series 180, American Chemical Society, Washington, 1982.

9. H-L. Li, D. H. Robertson, J. Q. Chambers and D. T. Hobbs, J. Electrochem. Soc., 135 (1988), 1154.

10. H-L. Li, J. Q. Chambers and D. T. Hobbs, J. Applied Electrochemistry, 18 (1988), 454.

11. H-L. Li, W. C. Anderson, J. Q. Chambers and D. T. Hobbs, Inorganic Chemistry, 28 (1989), 863.

12. F. A. Cotton and G. M. Wilkinson, Advanced Inorganic Chemistry, 3rd Edition, Interscience, New York, 1972, 52. 


\section{Appendix 1 \\ Calculated Species Fluxes into Catholyte \\ (Caustic Product Solution)}

$\begin{array}{lcc}\frac{\text { Test ID }}{\text { CR15 }} & \frac{\text { Element }}{\mathrm{Na}} & \begin{array}{c}\text { Flux } \\ \text { (mole/coulomb) }\end{array} \\ \text { CR17 } & \mathrm{Na} & 9.8 \mathrm{E}-06 \\ & \mathrm{Al} & 7.2 \mathrm{E}-06 \\ & \mathrm{Ca} & 2.4 \mathrm{E}-09 \\ \mathrm{CR} 18 & \mathrm{Na} & 1.2 \mathrm{E}-11 \\ & & \\ \mathrm{CR} 19 & \mathrm{Na} & 8.7 \mathrm{E}-06 \\ & \mathrm{Ca} & 1.0 \mathrm{E}-05 \\ & & 2.5 \mathrm{E}-11\end{array}$

a calculated from ICP-ES data using the following equation

Flux $=\left\{\left[\left(C_{f} \times V_{f}\right)-\left(C_{f} \times V_{f}\right)\right] /[1000 \times A W \times i]\right\}$

where, $\quad C_{f}$ is the final catholyte concentration $(\mathrm{mg} / \mathrm{L})$,

$V_{f}$ is the final catholyte volume (L)

$\mathrm{C}_{\mathrm{i}}$ is the initial catholyte concentration $(\mathrm{mg} / \mathrm{L})$

$V_{i}$ is the initial catholyte volume (L),

MW is the atomic weight of the element, and

$i$ is the total charge (coulombs) passed 


\section{Appendix 2A}

\section{Elemental Composition of CR15 Anolyte and Catholyte Solutions}

$\begin{array}{cccll}\text { Test \# } & \text { CR15 } & \text { CR15 } & \text { CR15 } & \text { CR15 } \\ \text { Type } & \text { Initial Anolyte } & \text { Final Anolyte } & \text { Initial Catholyte } & \text { Final Catholyte } \\ \text { ADS \# } & 3-85619 & 3-85620 & 3-85621 & 3-85622 \\ & \text { mg/L } & \text { mg/L } & \text { mg/L } & \text { mg/L } \\ \text { Ag } & \text { not determined } & \text { not determined } & \text { not determined } & \text { not determined } \\ \text { Al } & 2.96 \mathrm{E}+03 & 3.33 \mathrm{E}+03 & <5.01 \mathrm{E}+00 & <5.01 \mathrm{E}+00 \\ \mathbf{B} & 6.17 \mathrm{E}+01 & 6.78 \mathrm{E}+01 & <1.88 \mathrm{E}+00 & <1.88 \mathrm{E}+00 \\ \mathbf{B a} & <3.53 \mathrm{E}-01 & <3.53 \mathrm{E}-01 & <3.53 \mathrm{E}-01 & <3.53 \mathrm{E}-01 \\ \mathbf{C a} & <7.20 \mathrm{E}-02 & <7.20 \mathrm{E}-02 & <7.20 \mathrm{E}-02 & <7.20 \mathrm{E}-02 \\ \mathbf{C d} & <1.73 \mathrm{E}-01 & <1.73 \mathrm{E}-01 & <1.73 \mathrm{E}-01 & 1.73 \mathrm{E}-01 \\ \mathbf{C e} & \text { not determined } & \text { not determined } & \text { not determined } & \text { not determined } \\ \mathbf{C o} & <7.25 \mathrm{E}-01 & <7.25 \mathrm{E}-01 & <7.25 \mathrm{E}-01 & <7.25 \mathrm{E}-01 \\ \mathbf{C r} & 2.68 \mathrm{E}+01 & 3.08 \mathrm{E}+01 & <5.72 \mathrm{E}-01 & <5.72 \mathrm{E}-01 \\ \mathbf{C u} & 1.41 \mathrm{E}+00 & <7.95 \mathrm{E}-01 & <7.95 \mathrm{E}-01 & <7.95 \mathrm{E}-01 \\ \mathbf{F e} & 4.77 \mathrm{E}+00 & <5.83 \mathrm{E}-01 & <5.83 \mathrm{E}-01 & <5.83 \mathrm{E}-01 \\ \mathbf{L a} & <2.50 \mathrm{E}+00 & <2.50 \mathrm{E}+00 & <2.50 \mathrm{E}+00 & <2.50 \mathrm{E}+00 \\ \mathbf{L i} & 1.62 \mathrm{E}+00 & <7.57 \mathrm{E}-01 & <7.57 \mathrm{E}-01 & <7.57 \mathrm{E}-01 \\ \mathbf{M g} & 2.94 \mathrm{E}-01 & <6.10 \mathrm{E}-02 & <6.10 \mathrm{E}-02 & <6.10 \mathrm{E}-02 \\ \mathbf{M n} & <1.14 \mathrm{E}-01 & <1.14 \mathrm{E}-01 & <1.14 \mathrm{E}-01 & <1.14 \mathrm{E}-01 \\ \mathbf{M o} & 8.26 \mathrm{E}+00 & 9.42 \mathrm{E}+00 & <2.92 \mathrm{E}-01 & <2.92 \mathrm{E}-01 \\ \mathbf{N a} & 1.12 \mathrm{E}+05 & 8.13 \mathrm{E}+04 & 2.35 \mathrm{E}+04 & 3.93 \mathrm{E}+04 \\ \mathbf{N i} & <8.74 \mathrm{E}-01 & <8.74 \mathrm{E}-01 & <8.74 \mathrm{E}-01 & <8.74 \mathrm{E}-01 \\ \mathbf{P} & 1.51 \mathrm{E}+02 & 1.73 \mathrm{E}+02 & <2.08 \mathrm{E}+00 & <2.08 \mathrm{E}+00 \\ \mathbf{P b} & <4.77 \mathrm{E}+00 & <4.77 \mathrm{E}+00 & <4.77 \mathrm{E}+00 & <4.77 \mathrm{E}+00 \\ \mathbf{S i} & 1.93 \mathrm{E}+01 & 5.50 \mathrm{E}+00 & 8.55 \mathrm{E}+00 & <4.96 \mathrm{E}+00 \\ \mathbf{S n} & 2.85 \mathrm{E}+00 & 3.72 \mathrm{E}+00 & <8.44 \mathrm{E}-01 & <8.44 \mathrm{E}-01 \\ \mathbf{S r} & <1.43 \mathrm{E}-01 & <1.43 \mathrm{E}-01 & <1.43 \mathrm{E}-01 & <1.43 \mathrm{E}-01 \\ \mathbf{T i} & <4.50 \mathrm{E}-01 & <4.50 \mathrm{E}-01 & <4.50 \mathrm{E}-01 & <4.50 \mathrm{E}-01 \\ \mathbf{V} & <6.12 \mathrm{E}-01 & <6.12 \mathrm{E}-01 & <6.12 \mathrm{E}-01 & <6.12 \mathrm{E}-01 \\ \mathbf{Z n} & 2.36 \mathrm{E}+01 & 4.33 \mathrm{E}+00 & <1.45 \mathrm{E}-01 & <1.45 \mathrm{E}-01 \\ \mathbf{Z r} & <7.86 \mathrm{E}-01 & <7.86 \mathrm{E}-01 & <7.86 \mathrm{E}-01 & <7.86 \mathrm{E}-01 \\ & & & & \end{array}$




\section{Appendix 2B.}

Elemental Composition of CR17 Anolyte and Catholyte Solutions

\begin{tabular}{|c|c|c|c|c|}
\hline Test \# & CR17 & CR17 & CR17 & CR17 \\
\hline Type & Initial Anolyte & Final Anolyte & Initial Catholyte & Final Catholyte \\
\hline ADS \# & $3-89761$ & $3-89764$ & $3-89765$ & $3-89768$ \\
\hline & $\mathrm{mg} / \mathrm{L}$ & $\mathrm{mg} / \mathrm{L}$ & $\mathrm{mg} / \mathrm{L}$ & $\mathrm{mg} / \mathrm{L}$ \\
\hline $\mathrm{Ag}$ & $<1.82 \mathrm{E}+00$ & $<1.82 \mathrm{E}+00$ & $<1.82 \mathrm{E}+00$ & $<1.82 \mathrm{E}+00$ \\
\hline Al & $2: 19 E+03$ & $<5.01 \mathrm{E}+00$ & $7.04 \mathrm{E}+00$ & $2.90 \mathrm{E}+01$ \\
\hline B & $4.72 \mathrm{E}+01$ & $5.13 \mathrm{E}+01$ & $<1.88 \mathrm{E}+00$ & $<1.88 \mathrm{E}+00$ \\
\hline $\mathbf{B a}$ & $<3.53 \mathrm{E}-01$ & $<3.53 \mathrm{E}-01$ & $<3.53 \mathrm{E}-01$ & $<3.53 \mathrm{E}-01$ \\
\hline $\mathrm{Ca}$ & $1.64 E+00$ & $9.13 \mathrm{E}-01$ & $2.10 \mathrm{E}-01$ & $3.45 \mathrm{E}-01$ \\
\hline Cd & $<1.73 \mathrm{E}-01$ & $<1.73 \mathrm{E}-01$ & $<1.73 \mathrm{E}-01$ & $<1.73 \mathrm{E}-01$ \\
\hline $\mathrm{Ce}$ & $<1.95 \mathrm{E}+01$ & $<1.95 \mathrm{E}+01$ & $<1.95 \mathrm{E}+01$ & $<1.95 \mathrm{E}+01$ \\
\hline Co & $<7.25 \mathrm{E}-01$ & $<7.25 \mathrm{E}-01$ & $<7.25 \mathrm{E}-01$ & $<7.25 \mathrm{E}-01$ \\
\hline $\mathrm{Cr}$ & $7.06 \mathrm{E}+00$ & $7.91 \mathrm{E}+00$ & $<5.72 \mathrm{E}-01$ & $<5.72 \mathrm{E}-01$ \\
\hline $\mathrm{Cu}$ & $<7.95 \mathrm{E}-01$ & $<7.95 \mathrm{E}-01$ & $<7.95 \mathrm{E}-01$ & $<7.95 \mathrm{E}-01$ \\
\hline $\mathrm{Fe}$ & $2.78 \mathrm{E}+00$ & $<5.83 E-01$ & $<5.83 \mathrm{E}-01$ & $1.08 \mathrm{E}+00$ \\
\hline La & $<2.50 \mathrm{E}+00$ & $<2.50 \mathrm{E}+00$ & $<2.50 \mathrm{E}+00$ & $<2.50 \mathrm{E}+00$ \\
\hline $\mathbf{L i}$ & $1.36 \mathrm{E}+00$ & $<7.57 \mathrm{E}-01$ & $<7.57 \mathrm{E}-01$ & $<7.57 \mathrm{E}-01$ \\
\hline $\mathrm{Mg}$ & $3.30 \mathrm{E}-01$ & $1.73 \mathrm{E}-01$ & $<6.10 \mathrm{E}-02$ & $<6.10 \mathrm{E}-02$ \\
\hline Mn & $<1.14 \mathrm{E}-01$ & $<1.14 \mathrm{E}-01$ & $<1.14 \mathrm{E}-01$ & $<1.14 \mathrm{E}-01$ \\
\hline Mo & $7.67 E+00$ & $8.48 \mathrm{E}+00$ & $<2.92 \mathrm{E}-01$ & $9.32 \mathrm{E}-01$ \\
\hline $\mathbf{N a}$ & $8.51 \mathrm{E}+04$ & $1.24 \mathrm{E}+04$ & $2.24 \mathrm{E}+04$ & $7.80 \mathrm{E}+04$ \\
\hline $\mathbf{N i}$ & $1.36 \mathrm{E}+01$ & $3.23 E+00$ & $<8.74 \mathrm{E}-01$ & $<8.74 \mathrm{E}-01$ \\
\hline $\mathbf{P}$ & $1.08 E+02$ & $4.75 E+01$ & $<2.08 \mathrm{E}+00$ & $<2.08 \mathrm{E}+00$ \\
\hline $\mathbf{P b}$ & $7.43 \mathrm{E}+00$ & $<4.77 \mathrm{E}+00$ & $<4.77 \mathrm{E}+00$ & $<4.77 \mathrm{E}+00$ \\
\hline $\mathbf{S i}$ & $4.68 \mathrm{E}+01$ & $<4.96 \mathrm{E}+00$ & $<4.96 \mathrm{E}+00$ & $7.27 \mathrm{E}+00$ \\
\hline Sn & $7.86 \mathrm{E}+00$ & $4.83 E+00$ & $4.71 \mathrm{E}+00$ & $4.10 \mathrm{E}+00$ \\
\hline $\mathbf{S r}$ & $<1.43 \mathrm{E}-01$ & $<1.43 \mathrm{E}-01$ & $<1.43 \mathrm{E}-01$ & $<1.43 \mathrm{E}-01$ \\
\hline $\mathbf{T i}$ & $<4.50 \mathrm{E}-01$ & $<4.50 \mathrm{E}-01$ & $<4.50 \mathrm{E}-01$ & $<4.50 \mathrm{E}-01$ \\
\hline V & $<6.12 \mathrm{E}-01$ & $<6.12 \mathrm{E}-01$ & $<6.12 \mathrm{E}-01$ & $<6.12 \mathrm{E}-01$ \\
\hline $\mathbf{Z n}$ & $1.65 E+01$ & $<1.45 \mathrm{E}-01$ & $<1.45 \mathrm{E}-01$ & $3.17 \mathrm{E}-01$ \\
\hline $\mathbf{Z r}$ & $<7.86 \mathrm{E}-01$ & $<7.86 \mathrm{E}-01$ & $<7.86 \mathrm{E}-01$ & $<7.86 \mathrm{E}-01$ \\
\hline
\end{tabular}


Appendix 2C.

Elemental Composition of CR18 Anolyte and Catholyte Solutions

\begin{tabular}{|c|c|c|c|c|c|}
\hline Test \# & CR18 & CR18 & CR18 & CR18 & CR18 \\
\hline Type & Initial Anolyte & Initial Anolyte & Final Anolyte & Initial Catholyte & Final Catholyt \\
\hline ADS \# & $3-92981$ & 3-92982 & $3-92990$ & $3-92991$ & $3-92999$ \\
\hline & $\mathrm{mg} / \mathrm{L}$ & $\mathrm{mg} / \mathrm{L}$ & $\mathrm{mg} / \mathrm{L}$ & $\mathrm{mg} / \mathrm{L}$ & $\mathrm{mg} / \mathrm{L}$ \\
\hline $\mathbf{A g}$ & not determined & not determined & not determined & not determined & not determined \\
\hline Al & $3.03 E+03$ & $3.17 \mathrm{E}+03$ & $3.07 \mathrm{E}+03$ & $<5.01 \mathrm{E}+00$ & $<5.01 \mathrm{E}+00$ \\
\hline B & $5.92 \mathrm{E}+01$ & $6.55 \mathrm{E}+01$ & $5.86 \mathrm{E}+01$ & $<1.88 \mathrm{E}+00$ & $<1.88 \mathrm{E}+00$ \\
\hline $\mathbf{B a}$ & $<3.53 \mathrm{E}-01$ & $<3.53 \mathrm{E}-01$ & $<3.53 \mathrm{E}-01$ & $<3.53 \mathrm{E}-01$ & $<3.53 \mathrm{E}-01$ \\
\hline $\mathbf{C a}$ & $3.03 E+00$ & $3.13 E+00$ & $4.86 \mathrm{E}-01$ & $5.70 \mathrm{E}-01$ & $5.64 \mathrm{E}-01$ \\
\hline Cd & $<1.73 \mathrm{E}-01$ & $2.03 E-01$ & $<1.73 \mathrm{E}-01$ & $<1.73 \mathrm{E}-01$ & $<1.73 \mathrm{E}-01$ \\
\hline $\mathrm{Ce}$ & not determined & not determined & not determined & not determined & not determined \\
\hline Co & $<7.25 \mathrm{E}-01$ & $<7.25 \mathrm{E}-01$ & $<7.25 \mathrm{E}-01$ & $<7.25 \mathrm{E}-01$ & $<7.25 \mathrm{E}-01$ \\
\hline $\mathbf{C r}$ & $2.55 \mathrm{E}+01$ & $2.95 \mathrm{E}+01$ & $2.75 \mathrm{E}+01$ & $<5.72 \mathrm{E}-01$ & $<5.72 \mathrm{E}-01$ \\
\hline $\mathrm{Cu}$ & $<7.95 \mathrm{E}-01$ & $2.69 \mathrm{E}+00$ & $<7.95 \mathrm{E}-01$ & $<7.95 \mathrm{E}-01$ & $<7.95 \mathrm{E}-01$ \\
\hline $\mathbf{F e}$ & $5.11 \mathrm{E}+00$ & $6.32 \mathrm{E}+00$ & $<5.83 \mathrm{E}-01$ & $<5.83 \mathrm{E}-01$ & $<5.83 \mathrm{E}-01$ \\
\hline La & $<2.50 \mathrm{E}+00$ & $<2.50 \mathrm{E}+00$ & $<2.50 \mathrm{E}+00$ & $<2.50 \mathrm{E}+00$ & $<2.50 \mathrm{E}+00$ \\
\hline $\mathbf{L i}$ & $<7.57 \mathrm{E}-01$ & $3.03 E+00$ & $<7.57 \mathrm{E}-01$ & $<7.57 \mathrm{E}-01$ & $<7.57 \mathrm{E}-01$ \\
\hline $\mathbf{M g}$ & $3.88 \mathrm{E}-01$ & $4.26 \mathrm{E}-01$ & $<6.10 \mathrm{E}-02$ & $<6.10 \mathrm{E}-02$ & $<6.10 \mathrm{E}-02$ \\
\hline Mn & $<1.14 \mathrm{E}-01$ & $1.55 \mathrm{E}-01$ & $<1.14 \mathrm{E}-01$ & $<1.14 \mathrm{E}-01$ & $<1.14 \mathrm{E}-01$ \\
\hline Mo & $6.38 \mathrm{E}+00$ & $9.64 \mathrm{E}+00$ & $7.08 \mathrm{E}+00$ & $<2.92 \mathrm{E}-01$ & $<2.92 \mathrm{E}-01$ \\
\hline $\mathbf{N a}$ & $1.21 \mathrm{E}+05$ & $1.20 \mathrm{E}+05$ & $7.91 \mathrm{E}+04$ & $2.79 \mathrm{E}+04$ & $6.38 \mathrm{E}+04$ \\
\hline $\mathbf{N i}$ & $<8.74 \mathrm{E}-01$ & $2.15 \mathrm{E}+00$ & $<8.74 \mathrm{E}-01$ & $<8.74 \mathrm{E}-01$ & $<8.74 \mathrm{E}-01$ \\
\hline $\mathbf{P}$ & $1.36 \mathrm{E}+02$ & $1.51 \mathrm{E}+02$ & $1.44 \mathrm{E}+02$ & $<2.08 \mathrm{E}+00$ & $<2.08 \mathrm{E}+00$ \\
\hline $\mathbf{P b}$ & $<4.77 \mathrm{E}+00$ & $8.19 \mathrm{E}+00$ & $<4.77 \mathrm{E}+00$ & $<4.77 \mathrm{E}+00$ & $<4.77 \mathrm{E}+00$ \\
\hline $\mathbf{S i}$ & $1.25 \mathrm{E}+01$ & $3.10 \mathrm{E}+01$ & $7.91 \mathrm{E}+00$ & $<4.96 \mathrm{E}+00$ & $<4.96 \mathrm{E}+00$ \\
\hline Sn & $1.27 \mathrm{E}+00$ & $4.30 \mathrm{E}+00$ & $4.70 \mathrm{E}+00$ & $<8.44 \mathrm{E}-01$ & $<8.44 \mathrm{E}-01$ \\
\hline $\mathbf{S r}$ & $<1.43 \mathrm{E}-01$ & $1.65 \mathrm{E}-01$ & $<1.43 \mathrm{E}-01$ & $<1.43 \mathrm{E}-01$ & $<1.43 \mathrm{E}-01$ \\
\hline $\mathbf{T i}$ & $<4.50 \mathrm{E}-01$ & $8.28 \mathrm{E}-01$ & $<4.50 \mathrm{E}-01$ & $<4.50 \mathrm{E}-01$ & $<4.50 \mathrm{E}-01$ \\
\hline $\mathbf{V}$ & $<6.12 \mathrm{E}-01$ & $8.15 \mathrm{E}-01$ & $<6.12 \mathrm{E}-01$ & $<6.12 \mathrm{E}-01$ & $<6.12 \mathrm{E}-01$ \\
\hline $\mathbf{Z n}$ & $2.14 \mathrm{E}+01$ & $2.17 \mathrm{E}+01$ & $1.09 E+01$ & $<1.45 \mathrm{E}-01$ & $<1.45 \mathrm{E}-01$ \\
\hline $\mathbf{Z r}$ & $<7.86 \mathrm{E}-01$ & $9.31 \mathrm{E}-01$ & $<7.86 \mathrm{E}-01$ & $<7.86 \mathrm{E}-01$ & $<7.86 \mathrm{E}-01$ \\
\hline
\end{tabular}


Appendix 2D.

Elemental Composition of CR19 Anolyte and Catholyte Solutions

$\begin{array}{cllll}\text { Test \# } & \text { CR19 } & \text { CR19 } & \text { CR19 } & \text { CR19 } \\ \text { Type } & \text { Initial Anolyte } & \text { Final Anolyte } & \text { Initial Catholyte } & \text { Final Catholyte } \\ \text { ADS \# } & 3-94661 & 3-94665 & 3-94666 & 3-94670 \\ & \text { mg/L } & \text { mg/L } & \text { mg/L } & \text { mg/L } \\ \text { Ag } & \text { not determined } & \text { not determined } & \text { not determined } & \text { not determined } \\ \text { Al } & 2.48 \mathrm{E}+03 & 2.63 \mathrm{E}+03 & <5.01 \mathrm{E}+00 & <5.01 \mathrm{E}+00 \\ \mathbf{B} & 5.48 \mathrm{E}+01 & 5.54 \mathrm{E}+01 & <1.88 \mathrm{E}+00 & <1.88 \mathrm{E}+00 \\ \mathbf{B a} & <3.53 \mathrm{E}-01 & <3.53 \mathrm{E}-01 & <3.53 \mathrm{E}-01 & <3.53 \mathrm{E}-01 \\ \mathbf{C a} & 1.05 \mathrm{E}+00 & <7.20 \mathrm{E}-02 & <7.20 \mathrm{E}-02 & 1.84 \mathrm{E}-01 \\ \mathbf{C d} & <1.73 \mathrm{E}-01 & <1.73 \mathrm{E}-01 & <1.73 \mathrm{E}-01 & <1.73 \mathrm{E}-01 \\ \mathbf{C e} & \text { not determined } & \text { not determined } & \text { not determined } & \text { not determined } \\ \mathbf{C o} & <7.25 \mathrm{E}-01 & <7.25 \mathrm{E}-01 & <7.25 \mathrm{E}-01 & <7.25 \mathrm{E}-01 \\ \mathbf{C r} & 7.73 \mathrm{E}+00 & 6.09 \mathrm{E}+00 & <5.72 \mathrm{E}-01 & <5.72 \mathrm{E}-01 \\ \mathbf{C u} & <7.95 \mathrm{E}-01 & <7.95 \mathrm{E}-01 & <7.95 \mathrm{E}-01 & <7.95 \mathrm{E}-01 \\ \mathbf{F e} & 9.08 \mathrm{E}-01 & <5.83 \mathrm{E}-01 & <5.83 \mathrm{E}-01 & <5.83 \mathrm{E}-01 \\ \mathbf{L a} & <2.50 \mathrm{E}+00 & <2.50 \mathrm{E}+00 & <2.50 \mathrm{E}+00 & <2.50 \mathrm{E}+00 \\ \mathbf{L i} & <7.57 \mathrm{E}-01 & <7.57 \mathrm{E}-01 & <7.57 \mathrm{E}-01 & <7.57 \mathrm{E}-01 \\ \mathbf{M g} & <6.10 \mathrm{E}-02 & <6.10 \mathrm{E}-02 & <6.10 \mathrm{E}-02 & <6.10 \mathrm{E}-02 \\ \mathbf{M n} & <1.14 \mathrm{E}-01 & <1.14 \mathrm{E}-01 & <1.14 \mathrm{E}-01 & <1.14 \mathrm{E}-01 \\ \mathbf{M o} & 5.66 \mathrm{E}+00 & 5.05 \mathrm{E}+00 & <2.92 \mathrm{E}-01 & <2.92 \mathrm{E}-01 \\ \mathbf{N a} & 9.91 \mathrm{E}+04 & 4.82 \mathrm{E}+04 & 2.28 \mathrm{E}+04 & 6.07 \mathrm{E}+04 \\ \mathbf{N i} & 5.59 \mathrm{E}+00 & <8.74 \mathrm{E}-01 & <8.74 \mathrm{E}-01 & <8.74 \mathrm{E}-01 \\ \mathbf{P} & 1.14 \mathrm{E}+02 & 1.21 \mathrm{E}+02 & <2.08 \mathrm{E}+00 & <2.08 \mathrm{E}+00 \\ \mathbf{P b} & <4.77 \mathrm{E}+00 & <4.77 \mathrm{E}+00 & <4.77 \mathrm{E}+00 & <4.77 \mathrm{E}+00 \\ \mathbf{S i} & 2.67 \mathrm{E}+01 & 1.88 \mathrm{E}+01 & <4.96 \mathrm{E}+00 & <4.96 \mathrm{E}+00 \\ \mathbf{S n} & 2.37 \mathrm{E}+00 & 1.93 \mathrm{E}+00 & <8.44 \mathrm{E}-01 & <8.44 \mathrm{E}-01 \\ \mathbf{S r} & <1.43 \mathrm{E}-01 & <1.43 \mathrm{E}-01 & <1.43 \mathrm{E}-01 & <1.43 \mathrm{E}-01 \\ \mathbf{T i} & <4.50 \mathrm{E}-01 & <4.50 \mathrm{E}-01 & <4.50 \mathrm{E}-01 & <4.50 \mathrm{E}-01 \\ \mathbf{V} & <6.12 \mathrm{E}-01 & <6.12 \mathrm{E}-01 & <6.12 \mathrm{E}-01 & <6.12 \mathrm{E}-01 \\ \mathbf{Z n} & 1.96 \mathrm{E}+01 & 1.44 \mathrm{E}+01 & <1.45 \mathrm{E}-01 & <1.45 \mathrm{E}-01 \\ \mathbf{Z r} & <7.86 \mathrm{E}-01 & <7.86 \mathrm{E}-01 & <7.86 \mathrm{E}-01 & <7.86 \mathrm{E}-01 \\ & & & & \end{array}$




\section{Distribution:}

D. W. Geiser, DOE-HQ

P. McGinnis, ORNL

W. C. Laveille, 703-A

D. E. Kurath, PNNL

W. E. Lawrence, PNNL

R. E. White, University of South Carolina

J. W. Van Zee, University of South Carolina

J. W. Weidner, University of South Carolina

P. I. Hudson, 705-3C

C. W. McVay, $704-43 \mathrm{H}$

L. M. Papauchado, 773-A

C. R. Wolf, 773-A

W. L. Tamosaitis, 773-A

W. E. Stevens, 773-A

S. D. Fink, 773-A

S. T. Wach, 773-43A

J. L. Steimke, 786-5A

J. P. Morin, 719-4A

R. W. Brandon, 719-4A

B. L. Lewis, 703-H

J. R. Fowler, 704-Z

D. T. Hobbs, 773-A

IWT-LWP File, 773-A

TIM, 773-52A 